From the American Academy of Family Physicians

Ann Fam Med 2005;3:181. DOI: 10.1370/afm.277.

\section{PATIENT'S VOICE IN WASHINGTON}

\section{Academy Helps Family Physicians, Patients Learn About Health Care Legislation}

In a democracy, informed voters are the government. That premise is the driving force behind the enhanced Patient's Voice in Washington, the Academy-sponsored program that distributes information about important health-related issues to AAFP members and their patients.

The program provides a 2-pronged approach to ensuring that patients understand the legislative issues that can affect their health care. The first and new component comprises publication of "Issues in Health Care," an ongoing series of materials about public policy issues of importance to family physicians and their patients. The series' purpose is to inform and stimulate discussion in the community. The second component involves call-to-action alerts on critical legislative initiatives. Both elements rest on helping family physicians help their patients understand that government action can have a direct impact on their lives.

"This enhancement makes the Patient's Voice program so much more vital," said AAFP President Mary Frank, MD, of Mill Valley, Calif. "It makes patients more aware, and they'll start talking to their neighbors about what is going on. That's what grassroots is all about."

Douglas Henley, MD, AAFP executive vice president, agreed. "As the Academy has aggressively worked to enhance its advocacy efforts over the past 3 years, it's only a natural continuum that we look for ways to involve more of our members and, importantly, their patients in this effort," he said.

Family physicians can go to the Patient's Voice in Washington Web site (http://www.aafp.org/patientsvoice.xml) to download 1-page "Issues in Health Care" information sheets that provide facts about a health care topic and explain why the issue affects everyone, regardless of current insurance, income or health status.

"The Web site has several educational pieces about various health care topics that our members can download and place in their waiting rooms just for information to patients - not with the intent of stimulating messages to Congress, but simply to create better understanding of these important topics by patients," said Henley. The Academy can provide easels that hold the "Issues in Health Care" brochures.
The second prong — the call-to-action alerts began in February when AAFP asked members and their patients to encourage President Bush to increase pressure on Congress for a medical liability reform law. The impact of such grassroots action through the Patient's Voice in Washington can grow exponentially, said Frank.

"Patients become advocates for what they need in their own health care and for changes in the system that will help their doctors provide high-quality care to them," she said. "When you have each individual speaking out, contacting legislators, talking to neighbors, you develop a synergy, so that 1 plus 1 can equal 3 . And with the voice of many, there's a power that moves changes."

"There is nothing quite so persuasive to a member of Congress as lots of messages from constituents back home on an issue," said Henley.

The first 3 Patient's Voice in Washington topics - health care coverage for all, Medicaid, and family medicine training issues - went online early this year. A fourth informational sheet, which discusses the need to steer the health care system toward preventive care and services that help patients avoid complications from chronic conditions, was to be posted in early February. Two other topics will be added this year. Family physicians can check the Web site regularly for additions to the "Issues in Health Care" series.

The Patient's Voice in Washington offers several benefits, said Henley. In addition to providing an avenue by which family physicians and patients can express opinions to lawmakers, the program provides ongoing information about America's health care system and the role of family physicians in that system.

"This brings added value to patient-physician relationships," he added. "It brings more knowledge to our patients, including a better awareness of the Academy, a better informed and more involved member, and better debate and public discourse on important health care issues."

Leslie Champlin AAFP News Department

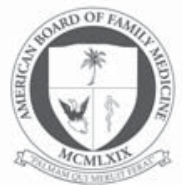

From the American Board of Family Medicine

Ann Fam Med 2005:3:181-183. DOI: 10.1370/afm.278.

\section{EXAMINATION DATES AND TEST CENTERS, 2004 PISACANO SCHOLARS}

The American Board of Family Medicine (ABFM) will administer its certification/recertification, sports medicine and adolescent medicine examinations exclusively 


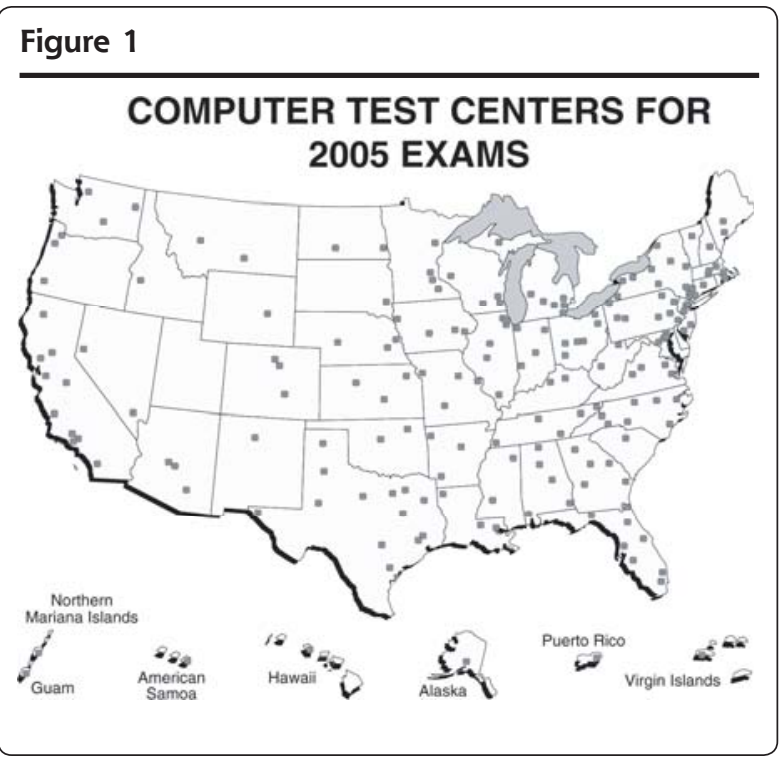

Table 1. ABFM 2005 Examination Dates

\begin{tabular}{lll}
\hline $\begin{array}{l}\text { Certification, Recertification, } \\
\text { and Sports Medicine }\end{array}$ & $\begin{array}{l}\text { Geriatric } \\
\text { Medicine }\end{array}$ & $\begin{array}{l}\text { Adolescent } \\
\text { Medicine }\end{array}$ \\
\hline $\begin{array}{l}\text { Thursday, Friday or Saturday } \\
\text { July 21, 22, 23, 28, 29,30 }\end{array}$ & $\begin{array}{l}\text { Wednesday } \\
\text { November 2 }\end{array}$ & $\begin{array}{l}\text { Thursday } \\
\text { December } 1\end{array}$ \\
$\begin{array}{l}\text { August 4, 5, } 6 \\
\text { December 2,* 3* }\end{array}$ \\
$\begin{array}{l}\text { * Limited eligibility - off-cycle residents, candidates with extraordinary circum- } \\
\text { stances precluding them from taking the July/August exam, and candidates who } \\
\text { are unsuccessful on the July/August exam. }\end{array}$ \\
\hline
\end{tabular}

on computer in 2005 . The certification/recertification and geriatric certification examinations will require 1 day; sports medicine, adolescent medicine, and geriatric recertification will require a half-day.

Certificiation/recertification, sports medicine, geriatric (certification/recertification) will be offered at more than 200 locations throughout the United States (Figure 1) (adolescent medicine locations were not available at deadline).

The number of examination dates has been increased to be offered on selected Thursdays, Fridays and Saturdays (Table 1). Expanded availability of dates and locations will help reduce the candidate's loss of income from practice, travel, and lodging expenses, as well as provide earlier results. For more information, please contact the ABFM Help Desk at 1-877-221-7437.

\section{Pisacano Scholars}

The Pisacano Leadership Foundation, the philanthropic arm of the American Board of Family Medicine, recently selected its Pisacano Scholars "Class of 2004." These 5 medical students follow in the footsteps of 46 scholar alumni who are practicing physicians and 20 current scholars who are attending medical school or are enrolled in family medicine residencies across the country. Since its founding 1993, the Pisacano Leadership Foundation has selected students who exhibit the qualities that typify the vision and legacy of Nicholas J. Pisacano, MD, the ABFM's founder and first executive director. Each Pisacano Scholar has demonstrated the highest level of scholarship, leadership, character, interpersonal skills and community service.

Molly Cohen, a 2004 Pisacano Scholar, is a fourthyear medical student at the University of Medicine and Dentistry of New Jersey, Robert Wood Johnson Medical School (UMDNJ). She received her BA in Biology at Rutgers College, graduating with highest honors from the General Honors Program. Molly was one of 11 Rutgers sophomores accepted into a 7-year joint BA/MD program through Rutgers University and Robert Wood Johnson Medical School, completing her first year of medical school during her junior and senior years of college. She was inducted into Phi Beta Kappa and Phi Eta Sigma national honor societies and was a member of the dean's list all 8 semesters at Rutgers. Upon graduation, Molly was awarded the S. Oakley Van Der Poel Award. During medical school, as the Homeless Project Coordinator for the Homeless and Indigent Population Healthcare Outreach Project (HIPHOP), Molly founded "Project HIPHOP," a program that provides medical students and physician assistant students with general volunteer opportunities in the New Brunswick community. In 2003, Molly was elected to the position of Student Director of the Healthcare Outreach Project (HOP) Clinic at UMDNJ, overseeing 47 student doctors who are the primary service providers for the clinic's uninsured patients, and helped obtain full coverage for the clinic's patients. In recognition of her work at the clinic, Molly received the AAFP Student Community Outreach Award at the 2004 National Convention. Molly looks forward to opening her own practice in an urban underserved area to combine physical healing with psychological and social care as a means of providing holistic treatment for her patients.

Jessica Dingman, a 2004 Pisacano Scholar, is a fourth-year medical student at Loyola University Chicago Stritch School of Medicine. She graduated magna cum laude from the University of Notre Dame with a BA in Anthropology. Jessica was named a Notre Dame Scholar during her freshman year and was a member of the dean's honor list all semesters in college. Jessica also volunteered in her community at a hospital and health clinic as a patient advocate. She was awarded the John R. Tobin Scholarship earlier this year and was also recently inducted into Alpha Sigma $\mathrm{Nu}$, a National Jesuit Honor Society, reserved for no more than $4 \%$ of 
the class. Jessica is currently the student president of the Illinois Academy of Family Physicians, serving on 2 of its committees. She is also the student membership liaison for the American Academy of Family Physicians and the secretary for Loyola's class of 2005. During the summer between her first and second year of medical school, Jessica participated in a medical mission trip to Haiti. As a family physician, Jessica envisions herself practicing the full spectrum of patient care while continuing to volunteer time at free clinics, or incorporating care for the underinsured into her own practice.

James Dolan, a 2004 Pisacano Scholar, is a fourthyear medical student at the University of Michigan (UM) Medical School. He also completed his undergraduate studies at UM, graduating with a double major in history and French. James has been accepted into an MPH program at UM's School of Public Health. Before beginning medical school, James traveled internationally for 11 years as a teacher and as a volunteer and employee for Habitat for Humanity and served as a coach for a number of high school and youth soccer teams. He has led 3 Habitat for Humanity work teams on international service projects. James most recently worked in Costa Rica for 2 years as a community development consultant for Habitat for Humanity. As a medical student, James cochaired the La Mesa Redonda, which is a group of medical students interested in furthering their spoken Spanish abilities. In addition, James volunteered with 2 migrant clinics. He participated in a mission trip to a hospital in Haiti, winning the inaugural Midwest Medwar with his team. Most recently, James started a wilderness medicine student interest group. As a family physician, James envisions working internationally in a capacity that will allow him to fulfill his humanitarian mission.

Oswaldo Grenardo, a 2004 Pisacano Scholar, is a fourth-year medical student at the University of Colorado School of Medicine. Oswaldo graduated from Stanford University with a BA in Human Biology, where he also earned a full football scholarship. He received a master's degree in Health Administration and an MBA from the University of Colorado. Immediately after college, Oswaldo and a partner started their own business, managing more than 30 employees. Oswaldo also created an annual alumni basketball tournament, providing scholarship money to underprivileged high school students. As the president of the Colorado Minority Health Forum, Oswaldo helped the Forum position itself to be the state leader in terms of promoting diversity in health care. In recognition of these efforts, he was named to 2 prestigious committees that were chosen by the governor of Colorado and the executive director of the Colorado Department of Health and Environment: the State Tobacco Education and Prevention Partnership Advisory Board and the Colorado Turning Point Initiative. Oswaldo currently works as an independent consultant, analyzing and negotiating managed care contracts for several medical providers. He was named by the dean of the medical school as the first Dean's Diversity Scholar, based on his interests in collaborative planning and utilization of resources toward racial and ethnic student recruitment and retention efforts. He is a member of the Student National Medical Association, the Colorado Medical Society Student Chapter, and Colorado's Family Medicine Interest Group. As a family physician, Oswaldo hopes to have a small practice and to be engaged in activities that encompass all aspects of a patient's care.

Eleni Spartos O'Donovan, a 2004 Pisacano Scholar, is a fourth-year medical student at the University of Massachusetts Medical School. She graduated magna cum laude with a BA in Medieval and Renaissance Studies from New York University (NYU). She was a 3-year member of the Dean's Scholars Program, a scholarship program focused on cross-cultural awareness and community service. Eleni was awarded the NYU Marco Polo Club Award for Excellence in Medieval Studies and NYU's Schuchard Anniversary Prize in German Literature. In addition, Eleni was the captain of NYU's Women's Varsity Fencing Team and received an NYU Scholar-Athlete Award at graduation. After graduating from NYU, Eleni taught high school English for 4 years, where she was the girls' varsity head track coach and wrote a grant to obtain funding from a local organization to start a health and wellness resource center at the high school. Her efforts led to the foundation of the Swampscott High Prevention Center. Before beginning medical school, Eleni received her master's degree in Maternal and Child Health from the Harvard School of Public Health. She became a Boston Schweitzer Fellow during her second year of graduate school and completed a year-long service project for the fellowship with the Youth Outreach Program of the Sierra Club. As a second-year medical student, Eleni started a new elective course in teen pregnancy. She was elected to UMass' 4-year Pathways Program. Her contributions were recognized by her peers last year when she received a student body Committee Leadership Award. Most recently, Eleni completed a 6-week health policy elective in the health committee office of Senator Edward Kennedy. As a National Health Service Corps Scholar, and through her previous experiences, Eleni plans on making her future professional home in a community health center. 